\title{
The Interpretation to Classic Lines of the Movie Roman Holiday from the Perspective of Politeness Principle
}

\author{
Li Wang \\ Xi’an Peihua University, Xi’an 710125, Shaanxi Province, China
}

Keywords: Roman Holiday, classic lines, politeness principle

\begin{abstract}
The principle of cooperation is an important guiding principle of conversation, but it is not the only principle. Grice, a famous language philosopher, also mentioned other principles such as politeness principles, aesthetic principles, social principles and so on, while the most notable one among the principles is the politeness principle. It is well known that Lakeoff put forward two principles of pragmatic competence in 1977, which are clarity and politeness. In 1978, Brown and Levinson put forward the theory of face management (Face-management View) based on face concept. They believe that the purpose of politeness is to maintain the face of both parties. In 1983 Leech proposed the politeness principle. It can not be denied that the principle of politeness plays an indispensable role in interpersonal communication, enabling people to communicate normally through dialogues. As a remarkable works in the film history, Roman Holiday has impressed many audiences all the time. Actually, the success of the movie is inseparable from its classic lines to some extent. Therefore, based on politeness principle, this paper attempts to analyse the classic lines of Roman Holiday through several groups of dialogues of the movie. The purpose is to make people have a profound understanding to the language art of Roman Holiday and better understand the importance of politeness principle in discourse application.
\end{abstract}

\section{Introduction}

Taken by American Paramount Company, the film Roman Holiday was released in 1953, which tells a romantic love story between an European Princess and an American reporter in Rome, Italy, within one day. Its director is famous William Wheeler. The two leading roles in the film were Gregory Peck (American reporter Joy) and Audrey Hepburn (Princess). Being a classic Hollywood black and white film, Roman Holiday won three Oscar prizes and also made Audrey Hepburn win the most important award of her life, Academy Award for Best Actress, making Audrey Hepburn known and loved by people all over the world. Roman Holiday is one of the classic films in the world so that many film industry experts have been appealed to carry on the research in its production method, photography, multidimensional appreciation, and so on. Besides, more and more language scholars have studied the linguistic features and style of the film. It is believed that there are too many factors to contribute to the film's success, and the language is one of the reasons. There is no doubt that language itself is an art. When the movie lines are integrated into the film through the actor's words and deeds, the film is given the soul. However, what principles should be followed to achieve the desired language effects when the lines are expressed in the film? This is worth pondering and discussing. So, in this paper, the author attempts to analyze several groups of dialogues selected from Roman Holiday based on the principle so as to explore the linguistic features of the film and help people have a profound understanding to the language art of the film, meanwhile, to make people better understand the importance of politeness principle in discourse application.

\section{The Theory of Politeness Principle}

Politeness is the symbol of human civilization and the rule of human activities. Politeness itself is a code of conduct with moral or ethical significance in the behaviors of daily life, including the efforts people are making in order to maintain the harmonious interpersonal relationship. In the eyes 
of Brown and Levinson, politeness is a Model Person's rational behavior in order to meet the needs of face.

It is well known that politeness comes into being in the interpersonal communication and it has always existed in all aspects of human life and changed with the development of human civilization. And dialogues are the main forms of communication among human beings, meanwhile, whether the communication among people can continue smoothly or not, depends on the extent of politeness of discourse, to a great extent. However, there are no lines and scripts in daily life, and what everyone says is the language of temporary organization, except for some specific occasions such as performance, conferences, speeches, and hosting. Therefore, in order to make the conversation proceed smoothly and effectively, it is necessary to follow certain principles for the normal dialogue and communication among people. Grice, a famous language philosopher, presented the Cooperative Principle (CP) for the first time in his speech at Harvard University in 1967. He believes that, during the process of communication, both sides of the conversation seem to consciously or unconsciously follow certain principles so as to cooperate and accomplish communicative tasks effectively. This is the principle of cooperation. And the principle of cooperation is an important guiding principle of conversation, but it is not the only one. Grice also mentioned politeness principles, aesthetic principles, social principles, and so on, but the most notable one is the politeness principle.

On the basis of previous studies, Lakeoff put forward two principles of pragmatic competence in 1977, namely, clarity and politeness. In 1978, Brown and Levinson put forward the theory of face management (Face-management View) based on face concept. They believe that the purpose of politeness is to maintain the face of both parties of conversation. In 1983 Leech proposed the politeness principle (Politeness Principle, PP). Politeness principle mainly includes the following standards: (1) Tact maxim (in impositives and commissives), a. to minimize the damage to others; $b$. to benefit others most; (2) Generosity maxim (in impositives and commissives), a. to minimize the benefit of yourself; b. to make yourself suffer the most; (3) Approbation maxim (in expressives and assertives), a. to try to narrow the derogatory to others; b. to try to exaggerate the praise to others; (4) Modesty maxim( in expressives and assertives), a. try to minimize praise for yourself; $b$, to try to exaggerate the derogatory to yourself; (5) Agreement maxim (in assertives), a. try to narrow the differences between you and others; b, try to exaggerate the consistency between you and others; (6) Sympathy maxim (in assertives), a. try to minimize your dislike for others; b, to try to exaggerate your compassion for others. However, some scholars in China believe that the politeness principle of Leech is too extreme and always emphasizes maximization and minimization, thinking that the principle of politeness is not applicable in many cases. In 1992, Xu Shenghuan pointed out that the six guidelines proposed by Leech were too absolute and idealized.

Based on the Leech's principle of politeness, according to the ethics of Chinese culture, Chinese scholar, Gu Yueguo, put forward the principle of politeness different from Leech's. They are respectfulness, modesty, attitudinal warmth, and refinement respectively. GuYueguo's view seems to be more in line with China's reality.

Actually, in most occasions, both in China and western countries, when people make dialogues, the influence of situation, status, relations and other factors should be taken into account in addition to the politeness principle. Therefore, taking the views mentioned above into consideration, based on the politeness principle, this paper tries to discuss the classical lines of the movie Roman Holiday, combination with situation, status, relations and other factors.

\section{The Synopsis of Roman Holiday}

Anne (Audrey Hepburn), a princess with the right of inheritance of an European country, was getting bored with her routinely restricted schedule when she was on a publicized tour to Rome. One night, she sneaked out of her luxurious residence and enjoyed the night view by herself. She was too happy and drank a lot wine and fell asleep on a public bench in central Rome at last. Fortunately, she was found by an American newspaper reporter, Joe Bradley ( Gregory Peck). In the end, Joe took her home without knowing who she truly was. And she stayed there for the whole 
night. But Joe accidentally discovered the true identity of the princess on the following day, and he decided not to expose it. And Joe and his friend, photographer Erwin ( Eddie Albert) together with the princess visited the Rome, and they met a lot of something interesting and funny, which made the princess so happy and unforgettable. Actually, Joe could make a big fortune by secretly interviewing the princess when the truth turned out, which he was longing for. But instead of that, after showing Ann around the whole city and having a good time with her, Joe forced himself to say farewell to the princess, for he knew that the romance between them oughtn't to be happened because of their great difference in status, even though they had fallen in love with each other deeply. Eventually, after Princess Ann had 24 hours of glorious freedom in Rome, she came to realize her responsibility to her family and her state and resolutely returned to the embassy.

\section{The Interpretation to Classic Lines of Roman Holiday Based on the Politeness Principle}

When it comes to Roman Holiday, it's hard to believe that the whole story takes place over more than 24 hours. During this short time, Princess Ann rebels from her old life, greedy to enjoy freedom as an ordinary girl, falls in love and grows up enough to accept her destiny. The plot of the film is so simple. And the relationships of characters are not complicated. Why do audiences still find its charm and the shock of the soul again? Why can a simple story be so vivid and interesting? It is believed that the reason is the exquisite arrangement, design of the characters, and its beautiful and classic lines. Therefore, in this chapter, the author will analyze several groups of dialogues selected from Roman Holiday based on the politeness principle to explore the linguistic features of the film, to help readers better appreciate this film.

\subsection{The Application of Agreement Maxim and Sympathy Maxim in the Movie Lines}

In the lines of the movie, the agreement maxim and the principle of sympathy are reflected incisively and vividly. Agreement Maxim means to try to narrow the differences between you and others and to exaggerate the consistency between you and others; while sympathy maxim means to try to minimize your dislike for others and try to exaggerate your compassion for others. People can understand the usage from the following dialogue between the princess and the ambassador after she came back from the outside:

Ambassador: Ma'am, you must appreciate that I have my duty to perform, just as Your Royal Highness has her duty.

Princess: Your Excellency, I trust you will not find it necessary to use that word again. Were I not completely aware of my duty to my family and my country, I would not have come back tonight. Or indeed, ever again. And now, since I understand we have a very full schedule today,you have my permission to withdraw.

After missing 24 hours, the princess finally came back. The ambassador said: "Sir, you must appreciate that I have my duty, as the princess has her duty." The princess answered: "Mr. ambassador, I believe you won't say so, if I don't know the responsibilities of my family and my country, and I won't be back tonight, maybe I should say I will never return.” It is obvious in the dialogue that the ambassador actually intended to blame the wayward princess, but he had to take into account the identity of the princess and the relationship between the monarch and his subjects, so, what he could do is only to seek the consistent place with the princess which was the responsibility. Only by following the agreement maxim can the ambassador not only achieve the effect of reproach, but also maintain the ceremony between him and the princess. Similarly, the princess was aware of her duty to the state and chose to come back at last. Actually, the ambassador knew that the princess was busy and tired everyday. Her words made the ambassador feel pity for the mischievous princess who was responsible for the country and the people. She successfully took advantage of the ambassador's sympathetic psychology. Therefore, the ambassador would not say anything more.

\subsection{The Application of Generosity Maxim, Approbation Maxim and Tact Maxim in Film Lines}

Generosity maxim means to minimize the benefit of yourself and to make yourself suffer the 
most; approbation maxim stresses to narrow the derogatory to others and try to exaggerate the praise to others; while tact maxim refers to minimizing the damage to others and benefiting others most.

As the heir of a country, Princess Anne is the representative of her country. It is required that she must be generous and decent in various official occasions. Besides natural exposure, she must smile at any time so as to show her love for the public. This paper cites a piece of news narration before the film's leading role appears. And so to Rome, the Eternal City, where the princess's visit was marked by a spectacular parade, highlighted by the band of the crack bersaglieri regiment. The smiling young princess showed no sign of the strain of the week's continuous public appearances. The narration shows that Princess Anne came to Rome after visiting many countries. From the facial expressions of the princess, she always kept smiling. So, ordinary people always think that the princess was not tired and the princess still was interested in the performance. In fact, generosity maxim has an intentional and unintentional restraint on the princess's performance. The princess of a country represents the image and etiquette of the whole country in public. Under this scenario, the princess shows her due state.

When the princess had a dinner at the Embassy in the evening and met all the guests, there is the following dialogues between the princess and the guest.

Emcee: His Highness, the Maharajah of Khani, and the Raikuuari.

Princess: I'm so glad you could come.

Guests: Thank you, madam.

In the dialogues, the speech of the princess is a good embodiment of the approbation maxim. During introducing guests, the princess, smiling, said, "I'm so glad you could come." to the couple Kennifu and Mahala. The princess was dignified and graceful, showing the style and politeness of the princess. It can be seen from the later story that although the princess keeps smiling, she has been very tired of this kind of life. She often needs sedative to help her to fall asleep. However, in such a solemn occasion, she still has to keep a consistent smile, and to praise other people more.

There is another dialogue between Joe and his landlord which can embody the tact maxim of the politeness principle effectively.

Joe: Swell! Thanks a lot. Oh er, Giovanni, er... How would you like to make some money?

Giovanni: Money?

Joe: Yeah. That's the stuff. Now look, I've got a sure thing: double your money back in two days.

Giovanni: Double my money?

Joe: Yeah well, I need a little investment capital to swing the deal. Now, if you'll just lend me a little cash, I...

The poor journalist, Joe, wanted to borrow some money from the landlord and take the princess out to play so that he could make a private interview with the princess. Joe didn't say "Can you lend me some money?" instead, he asked the landlord if he wanted to make a bit of money "How would you like to make some money." . Not only that, Joe also promised the landlord to double the amount of money, "I have got a sure thing: double your money back in two days." Actually, it is not a good thing for the landlord to borrow money, but Joe's humor and generosity to his landlord make his landlord realize that it is a big thing and be willing to lend money to him. Therefore, Joy got the money easily. The core content of tact maxim is: try to minimize the benefit of yourself and let others earn a profit, so as to get the favor of the other person, so that the communication can be carried out smoothly and gain greater benefits. Joe damaged his profits to a minimum in the expression of the language, maximizing the landlord's benefit, so he succeeded in borrowing money from the landlord. Therefore, in the design of the film dialogue, the proper use of generosity maxim and tact maxim of politeness principle, can play a humorous effect.

\subsection{The Use of Generosity Maxim and Modesty Maxim in Film Lines}

Generosity maxim means to minimize the benefit of yourself and to make yourself suffer the most; while modesty maxim emphasizes to minimize praise for yourself and to try to exaggerate the derogatory to yourself according to Brown and Levinson. 
Before and after the identity of Princess Anne was known, the languages used by Joe changed obviously, which embodied the two rules fully.

Princess: You're terribly nice.

Joe: Hey, come here. These are pyjamas, they're to sleep in. You're to climb into them.

Joe: Understand?

Princess: Thank you.

Joe: And you sleep on the couch. Not on the bed, on the couch. Is that clear?

Although the politeness principle requires people to follow the principle of generosity and humility, sometimes, more or less, their discourse will also be influenced by the identity and status of both parties. When Joe first met Anne, the language used by him was casual, especially when Princess Anne was drunk. Of course, it's a normal way to meet a drunk stranger. However, it is well known that the usage of language may be closely related to the relationship of speakers and their status. When Joe knew the identity of Princess Anne later, his words became subtle. Here's the conversation between Joe and Anne.

Princess: What time is it?

Joe: About one-thirty.

Princess: One-thirty! I must get dressed and go!

Joe: Why the hurry? There's lots of time.

Princess: No there isn't, and I've been enough trouble as it is.

Joe: Trouble? You're not what I'd call trouble. I'm not? I'll run a bath for you.

Before he knew Anne's identity, Joe threw his pajamas to her and ordered Anne to sleep on the sofa instead of the bed. After knowing Anne's identity, he slid into bed, and the tone of his speech became very gentle. When the princess said she had given him much trouble and hurried away, he hurriedly said that the time was too early and it was no trouble. He immediately volunteered to put the bath water for the princess. At this time, Joe tried to low his identity, thinking for the princess and benefiting the princess. Therefore, it is easily found from the group of dialogue that the language used by Joe is different at different times, and the use of politeness principle and the method of interpersonal communication are not the same because of different status and identity. Another group of dialogues between the journalist Joe with his boss are listed as following:

Hennessy: What do you care? You've got about as much chance of getting.

Joe: I know, but if I did, how much would it be worth?

Hennessy: Oh, just a plain talk about world conditions, it might be worth two hundred and fifty. Her views on clothes of course would be worth a lot more-maybe a thousand.

Joe: Dollars?

Hennessy: Dollars.

Joe: I'm talking about her views on everything: 'The Private and Secret Longings of a Princess'; her innermost thoughts as revealed to your own correspondent in a private, personal, exclusive interview. Can't use it, huh? I didn't think you'd like it.

The principle of modesty is to degrade oneself and to show modesty to others. In daily communication, it is often heard that some people praise themselves to disparage others, and this act of violation of the principle of politeness is called arrogance. In the character dialogue of the the movie, the example of the violation of the politeness principle is also seen everywhere. For instance, when Joe found that the woman sleeping in his own house was the princess, he told the boss that he could get all the news about the princess. He said“I'm talking about her views on everything: 'The private and secret longings of a princess'; her innermost thoughts as revealed to your own correspondent in a private, personal, exclusive interview. Can't use it, huh? I didn't think you'd like it.”. In fact, he exaggerated his ability. The purpose of Joe's violation of the politeness principle is to degrade the boss and weaken his sharpness. And the boss didn't believe what he said at all. So, the boss made a bet with Joe and gave Joe "dollars" after the success. "Oh, just a plain talk about world conditions, it might be worth two hundred and fifty. Her views on clothes of course would be worth a lot more-maybe a thousand.” From this dialogue, the example of violation of modesty principle can be found easily. The boss is a sarcastic, mercenary capitalist, while Joe is a representative of a 
rebel of the grassroots workers

\section{Conclusion}

To conclude, Roman Holiday is a timeless classic film, and its every line is intriguing and worth thinking by people. During the over sixty years, there are more and more researchers who are interested in analyzing its lines from various aspects so as to understand the essence of the film. This paper attempts to analyze the application of politeness principle in movie lines so as to make people have a profound understanding to the language art of Roman Holiday and better understand the importance of politeness principle in discourse application through several wonderful dialogues of Romantic Holiday. From what has been discussed above, it can be concluded that politeness principle can be applied to the movie dialogues to better understand the characters' personalities, the relationship between characters and their psychological activities. However, nowadays, in China, the research about the combination of politeness principle and other fields is still in a relatively backward state, and it is necessary for academic workers to make efforts to further research.

\section{References}

[1] AMY MURPHY. Traces of the Flaneuse from Roman Holiday to Lost In Translation [J].Journal of architectural education, 2006, 60(1):33-42.

[2] Marilyn A. Walker,Grace I. Lin,Jennifer E. Sawyer et al. An Annotated Corpus of Film Dialogue for Learning and Characterizing Character Style[C].//8th International conference on language resources and evaluation 2012, vol. 2: 8th International conference on language resources and evaluation 2012 (LREC-2012), 21-27 May 2012, Istanbul, Turkey.2012:1373-1378.

[3] Herlander Elias. The Bridge-A Transmedia Dialogue between TV, Film and Gaming[C].//Design, user experience, and usability. : Part I /.2014:548-559.

[4] LEONIE SANDERCOCK,GIOVANNI ATTILI. Digital Ethnography as Planning Praxis: An Experiment with Film as Social Research, Community Engagement and Policy Dialogue[J].Planning Theory \&amp; Practice,2010,11(1):23-45.

[5] A New Introduction to Pragmatics, He Zhaoxiong, Shanghai Foreign Language Education Press, 2000(2016 reprint), ISBN 978-7-81046-746-9/H.644. 